\title{
NILAI SOSIAL BUDAYA JEPANG DALAM PERIBAHASA JEPANG YANG MENGGUNAKAN KONSEP BINATANG
}

\author{
Sriwahyu Istana Trahutami \\ Program Studi Bahasa dan Sastra Jepang \\ Email : utami_undip@yahoo.com
}

\begin{abstract}
Proverbs conveying animal concepts can be found in almost languages. They are used to express indirectly the spesker's meaning. The data of the research are taken from Japanese Proverb Dictionary. This study used referential and inferential methods.The methods were used to determine life values in Japanese society or Japanese culture. This analysis reveals that in Japanese proverbs the animal like dog, cat, frog, snake, raccoon, tanuki, fish etc is often mapped on to human beings to expressing human relationship and to show characteristic of the Japanese people and culture.
\end{abstract}

Keywords : Animal proverb,life value, Japanese culture,

\section{PENDAHULUAN}

Kebudayaan merupakan sistem aturanaturan komunikasi dan interaksi yang memungkinkan suatu masyarakat terjadi, terpelihara, dan dilestarikan. Kebudayaan memberikan arti kepada semua usaha dan gerak-gerik manusia, dan adalah maknamakna kebudayaan ini, yang manusia sampaikan satu sama lain dalam hidup bermasyarakat.

Bahasa dan budaya merupakan dua sisi yang paling kompleks dalam kehidupan. Kebudayaan suatu masyarakat tidak dapat berkembang tanpa adanya bahasa. Bahasa terlibat dalam semua aspek kebudayaan, paling sedikit dengan cara mempunyai nama atau istilah bagi unsur-unsur dari semua aspek kebudayaan itu. Lebih penting lagi, kebudayaan manusia tidak dapat terjadi tanpa bahasa, bahasalah yang merupakan faktor terbentuknya kebudayaan

Menurut Halliday, salah satu fungsi bahasa adalah sebagai fungsi informatif, yaitu penyampai pesan dalam kegiatan berkomunikasi. Untuk menyampaikan suatu maksud kepada lawan bicara dalam komunikasi sehari-hari, acap kali dilakukan secara tidak langsung agar tidak menyinggung perasaan. Selain itu, ada kalanya maksud atau pesan lebih efektif dan tepat jika diutarakan melalui ungkapan tidak langsung. Masyarakat Jepang yang masih memegang tradisi ketimuran, terkenal akan basa basinya dalam mengungkapkan sesuatu. Hal ini bisa dilihat dari pemakaian bahasa masyarakat Jepang dalam berkomunikasi. Orang Jepang terbiasa mengungkapkan sesuatu secara tidak langsung diantaranya dengan sarana idiomidiom, termasuk peribahasa.

Makna yang terdapat dalam peribahasa merupakan hasil pengalaman, perenungan, dan pemikiran orang-orang tua dahulu dalam memahami hubungan antar manusia, manusia dengan karyanya, manusia dengan penciptanya, juga hubungan antara manusia dengan alam sekitarnya, yang dituturkan dari mulut ke mulut, dari generasi ke generasi.

Peribahasa terdapat pada semua bahasa yang ada di dunia ini, merupakan unsur bahasa yang dapat menggambarkan budaya suatu masyarakat bahasa pada zamannya atau unsur-unsur budaya yang memiliki nilai yang sebagian besar menjadi pedoman atau larangan dalam aktifitas manusia berbudaya. Hal ini dapat dipahami karena peribahasa tumbuh dan berkembang di tengah masyarakat yang berlatar belakang bahasa dan budaya penuturnya. 
Berdasarkan deskripsi latar belakang di atas, rumusan masalah yang akan dideskripsikan dan dianalisis dalam penelitian ini adalah sebagai berikut :

1. Apa saja nilai sosial budaya yang terdapat dalam peribahasa Jepang yang menggunakan konsep binatang.

Sedangkan tujuan dari penelitian ini adalah mendeskripsikan nilai social budaya masyarakat Jepang melalui konsep binatang yang digunakan dalam peribahasanya.

Melalui penelitian ini diharapkan dapat membantu memahami cara berpikir masyarakat Jepang, norma kehidupan yang dianut, dan nilai budaya yang tercermin dalam peribahasa Jepang

\section{LANDASAN TEORI}

\section{Fungsi Peribahasa}

Dalam Sekai Daihyakka Jiten 11 (1972:332), peribahasa Jepang berdasarkan fungsinya terbagi menjadi :

a. Kougekiteki kotowaza (peribahasa yang bersifat ofensif)

Peribahasa jenis ini biasanya digunakan sebagai senjata untuk mengadu kecakapan berbicara, juga digunakan untuk mengkritik dan menyindir lawan bicara atau musuh dalam suatu pertandingan, contoh : nou aru taka wa tsume kakusu 'orang yang berilmu biasanya rendah hati'.

b. Keikenteki kotowaza (peribahasa yang bersifat empirik)

Peribahasa yang digunakan untuk mengungkapkan pengalaman hidup. Peribahasa jenis ini menempati sebagian besar dari keseluruhan peribahasa Jepang. Isi peribahasa ini berhubungan dengan sikap hidup, pengetahuan, kepercayaan, yang bisa berbeda di tiap daerahnya. Juga berhubungan dengan teknik produksi seperti pertanian, perikanan, cuaca, dan pengetahuan tentang kehidupan. Misalnya : asa yakewa ame, yuuyakewa hare, jika fajar hujan, maka senja cerah. c. Kyoukunteki kotowaza (peribahasa yang bersifat didaktik)

Adalah jenis peribahasa yang mengandung pendidikan, ajaran moral, etika, nasihat, yang dapat dijadikan sebagai pedoman bagi seseorang dalam bertindak atau melakukan suatu perbuatan. Contoh terdapat pada inu wa mikka kaeba sannen no on o wasurenu 'orang yang tahu membalas budi'.

d. Yuugiteki kotowaza (peribahasa yang bersifat permainan)

Biasa digunakan untuk mengisi waktu pada saat tahun baru dengan beradu kemampuan menggunakan peribahasa

\section{Bahasa dan Nilai Budaya}

Bahasa merupakan sistem tanda yang berfungsi untuk mengkomunikasikan makna dari satu konsep pikiran ke yang lain, atau dari seseorang ke orang lain. Kebudayaan juga merupakan simbolsimbol, seperti halnya simbol bahasa, terjadi hubungan antara bentuk yang menandai dan makna yang ditandai. Sapir berpendapat bahwa bahasa merupakan petunjuk yang sifatnya simbolis terhadap budaya. Jadi bahasa sebagai sebuah hasil kebudayaan manusia merupakan simbol makna yang diciptakan untuk keperluan manusia dalam berkomunikasi.

Pandangan Sapir disempurnakan oleh Benyamin L. Whorf. Dia mengatakan bahwa cara memandang, cara memahami serta menjelaskan berbagai macam gejala atau peristiwa yang dihadapinya, sebenarnya sangat dipengaruhi oleh bahasa yang digunakannya. Bahasa yang dipakai masyarakat tanpa disadari mempengaruhi cara masyarakat tersebut memandang lingkungannya. Pandangan ini yang akhirnya terkenal dengan hipotesa Sapir Whorf. Dikatakan bahwa bahasa menentukan bukan hanya budaya tetapi juga cara dan jalan pikiran yang berbeda pula. Dengan kata lain suatu bangsa yang berbeda bahasanya akan berbeda pula jalan pikiran masyarakatnya. 
Kebudayaan adalah keseluruhan kecakapan-kecakapan (adat, akhlak, kesenian, ilmu, dan lain-lain) yang dimiliki manusia sebagai subjek masyarakat Dari sudut pandang antropologi kebudayaan diberi pengertian sebagai tata hidup, way of life, kelakuan. Dari definisi ini dapat ditarik kesimpulan bahwa kebudayaan adalah semua hal yang merupakan hasil karya cipta manusia sebagai subjek masyarakat. Termasuk dalam hal ini adalah bahasa yang merupakan hasil ciptaan manusia, digunakan oleh manusia, dan diturunkan dari generasi satu ke generasi berikutnya.

Kebudayaan (culture) bersinonim dengan cara suatu kelompok manusia (the ways of a people). Sehingga dapat dikatakan bahwa cara hidup orang Jawa adalah kebudayaan Jawa, demikian juga dengan cara-cara hidup orang Jepang dapat dipadankan dengan kebudayaan Jepang.

Sistem nilai budaya merupakan tingkat yang paling tinggi dan yang paling abstrak dari adat-istiadat. Hal itu karena nilai budaya merupakan konsep mengenai sesuatu yang ada dalam alam pikiran sebagian besar masyarakat yang dianggap bernilai, berharga, sehingga dapat berfungsi sebagai suatu pedoman yang memberi arah dan orientasi pada kehidupan warga masyarakat tersebut.

Nilai budaya dalam penelitian ini dipahami sebagai nilai yang mengacu kepada berbagai hal (dengan pemahaman seluruh tingkah laku manusia sebagai hasil berbudaya), antara lain mengacu kepada minat, kesukaan, pilihan, tugas, kewajiban beragama, kebutuhan, keamanan, hasrat, daya tarik dan lainnya yang berhubungan dengan perasaan dalam hubungannya antara manusia dengan manusia, manusia dengan alam, manusia dengan karya, manusia dengan waktu, dan manusia dengan penciptanya.

Sistem nilai budaya merupakan nilai inti dari suatu masyarakat. Nilai-nilai ini biasanya dijadikan atau tuntutan bagi individu anggota masyarakat tersebut untuk bertindak dan bertingkah laku.
Nilai-nilai tersebut dijunjung tinggi, diakui, dan diikuti semua anggota masyarakat. Di dalam sistem nilai biasanya terdapat konsepsi yang hidup di dalam alam pikiran sebagian besar warga masyarakat mengenai hal-hal yang dianggap bernilai dalam hidup. Sistem nilai ini berakar kuat dalam suatu masyarakat sehingga sulit berubah dalam waktu singkat.

Menurut C. Kluckhohn yang dikutip Koentjaraningrat tiap sistem nilai budaya dalam tiap kebudayaan mengandung lima masalah dasar dalam kehidupan manusia. Kelima masalah dasar dalam kehidupan manusia yang menjadi landasan bagi kerangka variasi sistem nilai budaya adalah :

a. Masalah hakikat dari hidup manusia

b. Masalah hakikat dari karya manusia

c. Masalah hakikat dari kedudukan manusia dalam ruang waktu

d. Masalah hakikat dari hubungan manusia dengan alam sekitarnya

e. Masalah hakikat dari hubungan manusia dengan sesamanya.

Cara berbagai kebudayaan di dunia mengonsepsikan kelima masalah universal tersebut berbeda-beda, walaupun kemungkinan untuk bervariasi itu terbatas adanya.

\section{METODOLOGI PENELITIAN \\ 1. Metode Penyediaan Data}

Metode penyediaan data yang digunakan dalam penelitian ini adalah metode simak, yaitu metode penyediaan data dengan menyimak penggunaan bahasa (Sudaryanto, 1988 : 2) Data peribahasa dikumpulkan dari sumber tertulis, baik dari buku kumpulan peribahasa Jepang, maupun dari kamus khusus tentang peribahasa Jepang, yaitu Koji Kotowaza Shinjiten, Shounen Shojo Kotowaza Jiten, dan Nihonno Kotowaza.

Peribahasa yang menggunakan nama binatang didata melalui pengartuan kalimat sederhana, dicari makna atau maksud peribahasa tersebut, dan digali nilai budaya apa yang dimiliki. Nilai-nilai budaya yang 
terdapat dalam peribahasa juga dipahami dari watak, sifat, dan karakter yang mewakili masyarakat dan budaya Jepang

\section{Metode Analisis Data}

Sedangkan untuk menganalisis data penulis menggunakan metode padan, atau disebut juga metode identitas (Sudaryanto, 1982 : 13). Metode padan adalah metode analisis data yang alat penentunya berada di luar, atau tidak menjadi bagian dari bahasa (langue) yang bersangkutan atau yang diteliti. Tujuan analisis data ini adalah untuk menentukan kejatian atau identitas objek penelitian. Identitas satuan lingual yang dijadikan objek penelitian ditentukan berdasarkan tingginya kadar kesepadanan, keselarasan, kesesuaian, atau kesamaannya dengan alat penentu yang bersangkutan yang sekaligus menjadi standar atau pembakunya. (Sudaryanto, 2003 : 19).

Metode padan yang digunakan pada penelitian ini adalah metode padan referensial yaitu untuk mengkaji makna kata yang menjadi kunci dari peribahasa, serta nilai budaya yang terkandung di dalamnya.

\section{Penyajian Hasil Analisis Data}

Hasil penelitian ini akan dirumuskan dengan menggunakan kata-kata biasa atau tidak formal (Sudaryanto, 1993 :45)

\section{HASIL DAN PEMBAHASAN}

Hampir semua bangsa mempunyai idiom-idiom yang menggunakan unsur binatang, demikian juga dengan Jepang. Timbul pertanyaan, apakah unsur binatang yang muncul pada idiom-idiom tersebut sama di semua bangsa? Dan apakah binatang yang sama mempunyai makna konotatif yang sama pula di semua bangsa? Misalnya, apakah'singa' mewakili makna berani, atau 'anjing' mewakili konotasi negatif di semua bangsa?

Dari data peribahasa yang menggunakan unsur binatang, diketahui bahwa binatang-binatang yang dianggap mempunyai manfaat untuk manusia atau yang dekat dengan kehidupan manusia sering muncul di dalam peribahasa. Termasuk binatang piaraan atau binatang ternak. Binatang yang muncul dalam data adalah anjing, kucing, burung, ikan, katak, kura-kura untuk binatang peliharaan. Ular, harimau, rase, tanuki, rusa, untuk binatang buas atau bukan peliharaan. Selain itu juga ditemukan serangga berbagai jenis dalam data. Nilai-nilai budaya yang direprentasikan pada peribahasa Jepang melalui konsep binatang dapat dirinci :

\section{Usaha Keras Pantang Menyerah}

Jepang dikenal sebagai Negara yang penduduknya penuh dengan sikap makoto atau kesungguh-sungguhan. Sikap ini menyiratkan bahwa orang Jepang mempunyai motivasi yang tinggi untuk maju.Sikap ini melahirkan etos kerja maupun kedisiplinan yang tinggi. Sikap untuk selalu berusaha dan bekerja keras ini tergambar pada contoh peribahasa :

1). Inumo arukeba bou ni atari 'jika berusaha pasti akan berhasil'

2). Tobu tori mo ochiru 'seorang pintar pun ada kalanya gagal'

3). Kouketsuni hairazunba koji o ezu 'tak ada keberhasilan tanpa usaha'

4). Uogokoro areba mizu gokoro 'jika ada kemauan pasti ada jalan'

Pada data ditemukan 12 peribahasa yang merupakan nasihat untuk tidak berputus asa. Kegagalan pasti ditemui semua orang. Berbekal kemampuannya manusia berusaha sekuat tenaga untuk memperoleh kesuksesan dan keberhasilan.

Usaha keras dan tidak putus asa ini direpresentasikan melalui konsep binatang anjing pada data 1 , burung pada data 2, harimau pada data 3 , dan ikan pada data 4 . Anjing, burung terbang, dan ikan koi adalah gambaran manusia yang seharusnya bekerja keras untuk memperoleh hasil, sementara anak harimau pada data 3 adalah representasi hasil yang akan diperoleh seseorang jika benar-benar berusaha bahkan mengambil resiko dalam usahanya tersebut. 


\section{Membalas budi}

Ajaran untuk membalas budi merupakan perwujudan konsep giri dan ninjou yang menjadi ciri khas budaya Jepang. Kata giri, memiliki beberapa arti, antara lain 'jalan yang benar untuk melakukan sesuatu hal atau perkara, budi pekerti'. Konsep ini berawal dari ajaran konghuchu yang merupakan dasar ajaran Shinto. Konsep giri ini dipakai dalam hubungan antar individu, dan merupakan tradisi yang sudah lama menyatu pada diri masyarakat Jepang, terutama pada masyarakat petani pedesaan.

Pada waktu menanam padi, jika seserang mendapatkan bantuan dari orang lain, maka dia mempunyai 'kewajiban' untuk membalasnya. Konsep giri merupakan akar terbentuknya perasaan 'berhutang budi' .

Sedangkan ninjou berarti kebaikan hati, kasih saying, tenggang rasa sebagai kodrat manusia. Ninjou menggambarkan pemahaman, pengertian terhadap kehidupan manusia di alam semesta ini. Para ahli berpendapat bahwa giri dan ninjou adalah satu kesatuan, namun ada ahli yang berpendapat bahwa giri dan ninjou merupakan hubungan timbal balik, atau saling berlawanan. Penempatan giri dan ninjou yang saling berlawanan ini dimaknai sebagai hubungan timbal balik antara pribadi dan umum dalam struktur masyarakat Jepang. Konsep giri ditempatkan lebih tinggi daripada ninjou.

Konsep giri dan ninjou inilah yang melahirkan kewajiban moral yang terdapat dalam kehidupan sosial masyarakat Jepang. Agar hubungan berjalan harmonis, jika seseorang mendapat kebaikan dari orang lain, maka dia mempunyai kewajiban moral untuk membalasnya. Sikap membalas budi terdapat pada data :

5). Kai inu nite o kamareta 'kebajikan dibalas kejahatan'

6). Inuwa mikka kaeba sannen on o wasurenu 'orang yang tahu balas budi'

7). Nekowa sannen on omikkade wasureru 'orang yang tidak tahu membalas budi'

Konsep anjing sebagai binatang peliharaan yang setia menjaga pemiliknya merupakan gambaran bagi orang yang dapat membalas kebaikan orang lain, seperti data no 6 . Demikian juga sebaliknya orang yang tidak dapat membalas budi digambarkan seperti anjing yang menggigit tangan pemiliknya pada data 5, dan seperti kucing yang dipelihara selama 3 tahun, namun tidak mengenal pemiliknya jika tidak bertemu dalam 3 hari.

\section{Realistis dalam Hidup}

Realistis adalah kondisi kejiwaan yang ada pada seseorang yang berupa kesanggupan untuk menerima kenyataan hidup yang telah dan sedang terjadi. Sikap ini terwujud pada sikap menerima kenyataan. Manusia sering dibelenggu oleh ambisi pribadi yang bisa membuatnya lupa diri. Karena harapan yang terlalu tinggi, manusia sering tidak bisa menerima kenyataan yang dihadapi. Tidak perlu mengharapkan sesuatu yang mustahil yang tidak akan terjadi. Sikap realistis ini tergambar dalam data peribahasa :

8). Sagi o karasu toiuyou 'mengikuti perbuatan orang lain tanpa berpikir'

9). Uno mane suru karasu 'meniru orang lain tanpa melihat kemampuan diri'

10).Saru no hito mane 'mengekor tindakan orang lain'

Burung gagak dan monyet mempunyai kebiasaan untuk meniru perbuatan atau tindakan manusia. Hal ini dikiaskan dalam peribahasa uantuk orang yang tidak menerima kenyataan hidup, hanya mengikuti perbuatan orang lain, tetapi tidak sadar akan kemampuan dirinya yang terbatas. Nilai yang bisa dipetik dari peribahasa ini adalah bahwa masing-masing orang pasti mempunyai kemahiran, kepandaian, atau mempunyai pesona yang tidak ada pada orang lain, sehingga merupakan nasihat agar kita realistis melihat kemampuan kita sendiri.

\section{Kewaspadaan Hidup}

Kewaspadaan hidup adalah sikap tanggap dan cekatan dalam menghadapi berbagai ancaman yang mengganggu kelangsungan hidup. Atau sikap hati-hati 
agar tidak mendapatkan musibah, celaka, atau masalah yang pada akhirnya merugikan diri sendiri. Nilai kewaspadaan hidup ini meliputi, berhati-hati dalam bicara, berhatihati dalam tindakan, jangan melakukan perbuatan ceroboh yang mendatangkan bahaya, koreksi diri, tidak sombong, dan menjaga hubungan baik dengan orang lain. Semua tindakan ini dilakukan agar tidak ada bahaya atau tidak ada masalah dalam hubungannya dengan orang lain. Nilai-nilai ini terdapat pada peribahasa :

11). Inuno touboe 'menceritakan kejelekan orang di belakang'

12). Kijimo nakasuba utaremai 'lebih baik tidak banyak bicara'

13). Torinaki sato no koumori 'sombong di hadapan orang yang lemah'

\section{4). Torano o o fumu 'mendekati bahaya'}

15). Yabu hebi 'tidak sengaja melakukan perbuatan yang mendatangkan celaka'

Menjaga lisan dalam berbicara dengan lebih baik tidak banyak bicara, dan tidak menjelekkan orang lain diwakili oleh konsep binatang anjing dan burung kiji (kuau). Hal ini dapat dipahami dari tindakan anjing yang suka menggonggong dari kejauhan, dan burung yang mencicit yang akan diketahui persembunyiannya oleh pemburu. Sehingga nilai yang ada pada peribahasa ini adalah nasihat untuk hati-hati berbicara agar tidak mendatangkan celaka pada diri sendiri. Sedangkan konsep ular dan harimau mewakili makna hal yang berbahaya, sehingga jangan sampai menginjak ekor harimau, atau mengeluarkan ular yang ada di semak belukar. Ini merupakan nasihat agar kita tidak ceroboh, berpikir sebelum bertindak.

\section{Ramah dan Dekat dengan Alam}

Masyarakat Jepang dikenal mempunyai kepedulian yang tinggi terhadap lingkungannya. Hal ini dapat kita lihat dari adanya taman kota di setiap kota yang luas, bersih, dan terawat. Juga pendidikan tentang kesadaran terhadap lingkungan yang diterapkan sejak dini melalui kyoiku mama. Bahkan pemerintah Jepang melalui Badan
Lingkungan Hidup (EA Environmental Agency) mensahkan "The Eco Life Pledge", atau janji ramah lingkungan yang disosialisasikan ke semua warga negara.

Kedekatan orang Jepang dengan alam sudah ada sejak jaman dahulu. Hal ini bisa dilihat pada buku berjudul "Kokuminsei Jukko" atau sepuluh ceramah tentang cirriciri kebangsaan, ditulis oleh Yaichi Haga tahun 1907, yang menyebutkan sepuluh karakter orang Jepang. Salah satu karakter orang Jepang adalah mencintai pohon-pohon dan bunga-bunga serta menyenangi alam. Kedekatan dengan alam juga ditemukan pada peribahasa dengan konsep binatang, yaitu :

16). Ten takaku ита коуии 'ungkapan indahnya musim gugur'

17). Tsubamega hikuku tobeba ame furu 'ungkapan hari akan hujan'

18). Amagaeruga nakeba amega furu 'ungkapan hari akan hujan'

19). Tobi takaku sorani maeba hare 'ungkapan hari akan cerah'

Orang Jepang memperhatikan keadaan alam untuk memprediksi cuaca, atau mengungkapkan keindahan suatu musim, dan menuangkannya melalui peribahasa. Jika burung tsubame terbang rendah atau kodok berbunyi maka hari akan hujan. Tetapi jika burung gagak terbang tinggi di awan maka sebaliknya hari akan cerah. Sementara data 16, konsep kuda juga digunakan untuk melukiskan keindahan alam yang didominasi warna daun merah (momiji) pada saat musim gugur.

\section{Sikap Hormat dan Santun}

Dengan adanya sikap giri dan ninjou seperti pembahasan sebelumnya (balas budi), melahirkan sikap hormat, terutama kepada orang yang lebih tua atau terhadap orang tua, juga sikap santun terhadap sesama. Orang tua telah memperhatikan anak-anaknya, maka sepantasnya anak berkewajiban hormat terhadap mereka.

Pada Sepuluh Ceramah tentang Ciri Kebangsaan, juga disebutkan bahwa watak 
orang Jepang adalah hormat terhadap nenek moyang dan menghargai nama keluarga. Peribahasa yang merupakan gambaran dari sikap ini terdapat pada :

20). Tora wa ko o omoute senri e kaeru 'orang tua selalu memikirkan anak'

21). Kameno kou yori toshino kou 'orang tua kaya pengalaman dan keberhasilan'

22). Hatoni sanshi no rei ari karasu ni hanpou no kou ari 'anak yang santun pada orang tua'.

Harimau (data 20 ) mempunyai makna orang tua yang bertanggung jawab terhadap anaknya, sebagai bentuk kewajiban orang tua. Sementara sebagai anak wajib menghargai orang tua, seperti burung merpati yang selalu bertengger di dahan yang lebih rendah daripada dahan induknya. Dan nasihat agar jangan seperti burung gagak yang selalu menyambar makanan yang ada di mulut induknya (data 22). Kurakura pada (data 21) adalah gambaran seseorang yang berumur panjang, seperti kura-kura. Peribahasa ini digunakan untuk menyanjung, memberikan penghargaan terhadap orang tua yang banyak pengalaman dalam hidup.

\section{KESIMPULAN}

Sebagai orang timur, masyarakat Jepang terbiasa mengungkapkan maksud secara tidak secara langsung, salah satunya melalui idiom, termasuk di dalamnya adalah peribahasa. Peribahasa merupakan salah satu kearifan lokal yang diturunkan terusmenerus dari satu generasi ke generasi berikutnya. Dalam peribahasa ini terkandung ajaran, nasihat, dan nilai-nilai kebijakan hidup lainnya, sehingga tidak berlebihan jika dikatakan dari peribahasa ini kita mengetahui watak serta karakter masyarakat tempat hidup dan berkembangnya peribahasa tersebut.

Jepang, seperti halnya Negara kita, termasuk dalam lingkungan kebudayaan agraris atau inesaku bunka. Dahulu, mata pencaharian pokok penduduknya adalah bercocok tanam padi di sawah, yang dimulai sejak jaman Yayoi yang berlangsung dari 200 SM hingga 300 M. Peribahasa Jepang tumbuh dan berkembang dalam lingkungan masyarakat ini yang biasanya dituturkan orang-orang tua untuk memberikan nasihat kepada yang lebih muda dengan tujuan memuja dewa sehingga hasil panen dapat melimpah ruah untuk persediaan musim dingin. Selain itu peribahasa juga digunakan untuk menyampaikan teknik-teknik pertanian dan bercocok tanam yang diperlukan masyarakat pada saat itu. Melalui kalimat yang ringkas dan padat, tentu peribahasa ini akan mudah diingat.

Dari latar geografis masyarakat penuturnya, tidak mengherankan jika di dalam peribahasa Jepang banyak ditemukan peribahasa yang menggunakan simbol binatang, tanaman, yang akrab dengan keseharian mereka. Binatang yang ditemukan dalam peribahasa Jepang antara lain anjing, kucing, rase, tanuki, ular , kodok, ikan, kura-kura, burung dan sebagainya. Binatang-binatang yang muncul dalam peribahasa Jepang adalah binatang ternak, binatang piaraan, juga binatang yang dekat dengan kehidupan manusia sekalipun binatang buas seperti ular dan harimau. Burung, ikan, dan serangga dengan berbagai jenisnya merupakan binatang yang terbanyak muncul dalam data peribahasa. Hal ini menunjukkan bahwa binatang-binatang ini yang dianggap paling dekat dengan budaya orang Jepang.

Penelitian tentang peribahasa yang menggunakan binatang ini menegaskan bahwa manusia sejatinya merupakan hewan yang berakal dan mempunyai perasaan. Namun sifat dan tabiat binatang banyak yang terdapat pada diri manusia. Sehingga peribahasa dengan konsep binatang ini penulis anggap tepat untuk menggambarkan sosok manusia dengan berbagai karakternya. Kehidupan hewan adalah contoh yang paling sesuai dan produktif untuk memahami sifat manusia. 


\section{DAFTAR PUSTAKA}

Danandjaja, James. 1997 Folklore Jepang. Dilihat dari Kacamata Indonesia. Jakarta : Pustaka Utama Graffiti.

Kaneko Takeo. 1983. Nihon no Kotowaza Vol. 1 -4.Tokyo : Kaikan Shouten

Koentjaraningrat. Edisi Revisi 2009. Pengantar Ilmu Antropologi. Jakarta : PT. Rineka Cipta.

Matsui Yoshikazu, 1991. Nihonjin no Kangaekata (Nihonron e no annai). Tokyo : The Japan Foundation
Mizue, Sasaki. 1995. "Nihon no kotowaza" dalam Nihon Jijou handobukku.

Tokyo: Japan. Daishuukanshoten.

Sankou Shuppan. 1994. Koji Kotowaza Shinjiten. Toukyou: Sankou Shuppan.

Yasuo, Kitahara. 1996. Shounen Shoujou Kotawaza Jiten. Tokyo : Shogakukan. 